Dicenda. Cuadernos de Filología Hispánica

ISSN: 0212-2952

hhttp://dx.doi.org/10.5209/DICE.57708

\title{
Hermenéutica del título en la poesía áurea: la transmisión textual de la obra burlesca de Góngora ${ }^{1}$
}

\author{
Juan J. Martínez García ${ }^{2}$
}

Resumen. En el estudio se reflexiona sobre las funciones de los títulos de género (décima, romance, soneto, letrilla, etc.) y de "materia" (satírico, burlesco) y, en menor medida, de los epígrafes en la poesía del Siglo de Oro. En el caso de Luis de Góngora, que nunca asigna títulos ni, por supuesto, epígrafes a esta clase de poemas, la transmisión textual de su obra no se entiende sin la cuestión sobre la paratextualidad.

Se revisan los conceptos de nombre, predicable y universal para justificar la existencia de una figuración icónica que liga el título y el poema mediante un indéxico oculto, externo a la enunciación (el clístico), en manuscritos e impresos de la obra de Góngora, principalmente la burlesca y la satírica.

Palabras clave: Título; epígrafe; Siglo de Oro; Góngora; poesía burlesca y satírica; iconicidad.

\section{[en] Hermeneutics of the title in the Golden poetry: the textual transmission of the burlesque works of Góngora}

\begin{abstract}
The study reflects on the function of the titles of the different genres (décima, ballad, sonnet, letrilla, etc.) and subgenres (satirical, burlesque) and, on a lower scale, of the epigraph in the poetry of the Golden Age. For Luis de Góngora, who never assigns titles nor, of course, epigraphs to these type of poems, the textual transmission of his work requires paratextuality.

Concepts such as name, predicable and universal, used to demonstrate the existence of an iconic figure which joins the title and the poem through a hidden indexical, external to the statement (the "clistic"), in manuscripts and printed poetical works by Góngora, mainly burlesque and satire, are revised.

Keywords: Title; epigraph; Golden Age; Góngora; burlesque and satirical poetry; iconicity.
\end{abstract}

Sumario. 1. Concepto: ucronías y alegorismos. 1.1. Asimetrías: opacidad y causalidad. 2. Simetrías: predicables y epojé. 2.1. Dimensiones. 2.2. Funciones. 2.3. Acercamientos. 2.4. Función clística y sentido. 2.5. Proporción y logos

Cómo citar: Martínez García, J.J. (2017). Hermenéutica del título en la poesía áurea: la transmisión textual de la obra burlesca de Góngora, Dicenda. Cuadernos de Filología Hispánica, 35, 205-225.

\footnotetext{
1 Este artículo es una versión ampliada del que aparecerá en mi tesis doctoral con el título "Acerca de los títulos icónicos en la transmisión textual de las letrillas de Góngora" (Martínez García, 2015: 266-288).

2 Universidad de Málaga.

jjmar2002@uma.es
} 
En los principales manuscritos y ediciones, antiguas y modernas, la poesía gongorina se clasifica atendiendo al género - si bien con absoluta falta de convicción- y/o por orden cronológico, pero

¿quién decide si una determinada composición debe considerarse burlesca, satírica o amorosa? Evidentemente, no los autores, de quienes apenas conocemos su opinión al respecto, sino los recolectores, que ordenan las poesías de acuerdo a unos criterios 'tradicionales', lo que obligaba a decidir el marbete con el que iban a catalogar cada composición (Pérez Lasheras, 1995: 39).

Aunque Góngora nunca encasilla sus especies poéticas, sus amigos y discípulos, siguiendo la huella de la poesía italiana, intentan poner orden en el desconcierto manuscrito - excesiva ingenuidad en el gobierno de las artes de la divisio- y les asocian un título de clase mediante un nombre común (romance, décima o canción, entre otros), lo que conduce a que las ramas de la isagogé — arraigadas en el género soberano (genikótaton) - pierdan su firmeza en el conato de análisis del subgénero, la especie última (eidikótaton).

En el apartado "Disposiciõ destas obras" de los preliminares del manuscrito Chacón se observan las dificultades de clasificación que un conjunto tan diverso de poemas le plantea al compilador en una obra que se pretende completa:

QVE aunque la eminencia de las Obras de D. Luys permitía sacarlas de lo común, y que en la disposición de su orden sucesiua se atendiese, como en los Poetas Latinos, a la diferencia de los estilos, el temor de que este nueuo modo de colocación no las confunda, i la imitación del Maestro Francisco Sánchez Brócense, i de Hernando de Herrera, que en las impressiones de las obras de Garci-Lasso han seguido en esto a las de Poetas Italianos, ha obligado a diuidir, i graduar estas Obras según los géneros de sus versos. Si bien en cada vno van subdiuididas las materias ${ }^{4}$, i colocadas en el lugar que parece se deue a cada vna (Góngora, 1991: Advertencias).

Clasificación medieval de los tópicos del Órganon aristotélico según la perspectiva ontológica de Porfirio (Boecio, 1906: 1, 10-11, 23).

4 Satírico, burlesco, sacro, moral, fúnebre, amoroso, heroico, lirico y vario son las "materias" en que, asimétricamente, los principales testimonios antiguos (incluido Chacón) dividen la obra de Góngora, sin embargo, en la edición de los hermanos Millé hay confusión entre "materia" y "género de los versos" (Góngora, 1932: 28-31). "Lírico" indica reflexión, en tanto que "sacro", "fúnebre" y "amoroso", por su parte, denotan relaciones proyectivas (ya sean transitivas o intransitivas). Más íntima es la ilativa del sujet "heroico" con su predicado, ya que la observancia del aptum que describe el término resume la intransitividad pura, analítica, en las antípodas de lo "burlesco" y lo "satírico" (lo medular en este trabajo), cuya falta de decorum conduce a Hoces (Góngora, 1633) y al editor de las Delicias del Parnaso (Góngora, 1634) a reducir ambos a lo burlesco. Tal confusión afecta a las décimas: ya que no las hay morales, ni sacras ni heroicas, el colector se resigna a agruparlas entre las varias. El enredo textual afecta a las ediciones más modernas de la obra completa. La de Foulché-Delbosc sigue el criterio cronológico y no aborda el problema del género ni en el prólogo (Góngora, 1921: I, xv-xvi), en tanto que la de los Millé (Góngora: 1932: 30-1) distribuye las poesías en formas métricas ("materias", en el original) como ya hiciera Adolfo de Castro (1854: I, 425-553). La edición parcial no evita la cuestión: en canciones, madrigales, tercetos, silvas, octavas (Góngora: 1990: 14-15) y romances (Góngora, 1998: 47) se procede cronológicamente, pero la disposición en "materias" de sonetos (Góngora, 1981: 1) y letrillas, y la cuestión en torno a lo satírico-burlesco (abominable concepto) planteada por Jammes en su edición en español de estas últimas (Góngora: 1980: 20-21) han atascado un debate en el que algunos buscan un resquicio: la edición de Góngora "debería comenzar diferenciando lo serio de lo jocoso [...]: en Góngora pueden ser festivos o burlescos no sólo poemas amorosos, líricos y satíricos, sino también los heroicos, los sacros y hasta los fúnebres" (Carreira, 1998: 363). 
La falta de crédito filológico con que editores y amanuenses ${ }^{5}$ ajustan lo que de natural ("las materias") no pretende ser ajustado — no se olvide que Góngora es tan raudo en deshacerse de la obra como espaciado en su lustre ${ }^{6}$ - es la prueba del habitual conflicto entre el ethos del poeta y la fidelidad in officium del compilador. En ese sentido, Góngora es vate, un profeta que vaticina el destino final de su obra: el cartapacio ajeno, un ingenio del mundo factual del clérigo cordobés que lo muestra como poeta con los modos de un tercero ${ }^{7}$.

En la fronte deliberativa - factual por mediadora- del compilador recae la extraña labor de acomodar la bifronte del clérigo y del poeta. Este ajuste legitima la función de recopilación, pero la fórmula del fenómeno sigue abierta: necesita ingresar de alguna manera la correspondiente fronte singular de lector, que no está

Fiel a sí mismo, el mencionado autor, en su edición de la obra completa (por donde cito), divide "en cada forma métrica, primero lo serio, luego lo festivo" (Carreira, 2000: xxiv). Véase la nota 8.

5 Los prosélitos de Góngora son, de suyo, compiladores o colectores, incluso cazadores de la pieza poética, y ejercen la función subsidiaria de amanuense. En palabras de Pedro Espinosa: "para sacar esta flor de harina he cernido dozientos caýzes de poesía, que es la que ordinariamente corre" (Espinosa, 2005: dedicatoria "Al lector”). Algunos, como Juan López de Vicuña (Góngora, 1963) o Gonzalo de Hoces son, además, editores (esto es, suplican la Licencia y el Privilegio que otorga la Pragmática del momento) pero, lógicamente, no impresores. Al final, los poemas acaban en manos de copistas de prestigio (caso del manuscrito Chacón) o, en los impresos, además, de cajistas.

6 Así lo advierte A. Chacón en el prefacio de su manuscrito: "Si bien jamas assistio à la disposicion de alguno. [...] fueron raras las que escrivio de su mano. y en su poder jamas conservò alguna" (Góngora, 1991: Advertencias). "Esta es la paradoja permanente de la creación gongorina: el extraordinario cuidado con que se compuso cada poesía, cada copla, cada verso (en una época de abundancia y facilidad poéticas), y el increíble descuido de su autor en todo lo que tocaba a la transmisión, y hasta a la mera conservación de su obra" (Góngora, 1980: 22).

7 Los epígrafes (que, con el título, secundan la función didascálica) son un buen ejemplo porque parecen ser obra del colector y de los comentaristas: "Esto nos hace preguntarnos si los poemas de don Luis salieron de sus manos con o sin epígrafes [...], no parece probable que si los hubiera los copistas los hayan suprimido" (Carreira, 2013: 81). Si esto es así, epígrafes como los de los sonetos 29, 143 y la décima 381 ("En la muerte de una señora que murió moza en Córdoba", "Al mal clima de Valladolid y a su confusión en tiempos de la corte" y "De un perrillo, que se le murió a una dama, estando ausente su marido") son constituyentes articulados de aquellos contenidos que el comentarista cree privativos del poema como "ejemplar" (token) —esto le diferencia del título, que articula siempre una clase o "tipo" (type) - y, por lo tanto, necesarios para su inteligencia. Y aunque Alonso Veloso observa en su notable artículo que "Los epígrafes — término que considero equivalente a la actual acepción de 'título'- eran por lo general una síntesis del tema del poema" (2012: 94), la distinción es tozuda: hay epígrafes diversos sobre el mismo asunto (véanse la nota 70 y Carreira, 2013: 81-90). La causa formal de tanta imprecisión reside en que el epígrafe altera el rasgo de iconicidad bipartita de la figura "título / poema" cuando se inserta entre ambos, y con frecuencia orienta la interpretación hacia el mundo de creencias de la voz ajena que lo articula, pero la orientación se vuelve instrucción si el epígrafe abandona su ámbito tipográfico, el de la inscriptio, en el (forzado) icono "título / epígrafe / poema". El ms. Chacón contiene algunas notas marginales que no llegan a truncar el icono, pero el ms. Rennert (Codex 187 de la Universidad de Pensilvania), en su extenso Índice Alphabethico de las Poësias, incluye algunos assumptos, $i$ advertencias a dichas Poësias. La lectura poética resultaba tan fastidiosa que alguien "se tomó el trabajo de copiar muchos de ellos al margen de cada poema con distinta letra” (Carreira, 1998: 110 ss.). Este moderno escoliasta notó que el ascenso temporal y espacial de la advertencia respecto del poema (que permanece latente, implícito, como parte del icono) vulneraba la convención de lectura, y se apresuró a restablecerla según costumbre aun no arraigada, pero a la que contribuyen manuscritos e impresos (aunque Vicuña sólo presente epígrafes en los sonetos). Hoces y Chacón despliegan inscripciones en canciones, madrigales, silvas, octavas, tercetos, décimas y algunas letrillas sacras, y Chacón, incluso en quintillas y redondillas. Hoces, por su parte, hace lo propio en un par de letrillas burlescas, especialmente “Arroyo, ¿en qué ha de parar?” (447, véase la nota 70) y en unos pocos romances. Hay también manuscritos integri (2892 BNE, 19003 BNE, B2465 HSA, B2362 HSA, 147 BUB y B87-V3-10 B. March) con abundantes epígrafes, especialmente, en los poemas en endecasílabos. Véase la nota 9. 
apoderado para modificarlos contenidos del cartapacio ${ }^{8}$. Hay tantas intrusiones en este engranaje $^{9}$ que — salvado Ockham- parece necesario lubricar sus mecanismos esenciales.

\section{Concepto: ucronías y alegorismos}

No es cosa nueva que el nombre suscita correspondencias con las cosas del mundo $\mathrm{y}$, en cuanto nombre de la obra, los lectores se acercan al título ${ }^{10}$ con afán designativo, esto es, con la intención de ajustar el nuevo mundo poético que se encuentra en espera - por remático - con el mundo factualmente cercano del compilador, quien acaba otorgándole, con afán no designativo, un nombre impropio. En esas idas y

8 Además de afectar a la obra completa, la inconsistencia en cuanto al género puede arruinar un poema determinado. A vuelapluma: en el ms. B2465 HSA, la décima atribuida "Pues es lunes, con que empieça" consta de cuatro espinelas, las tres primeras burlescas y la última, "Señor marqués trinitario", la única editada (426), satírica (Pezzini, 2013: 108-109). A otros no los arruina, pero los castiga. "Que se nos va la pascua, mozas" (26) es un romance con estribillo sobre el que algún propietario no pudo dejar de sobrescribir letrilla (ms. 4118 $\mathrm{BNE}$ ), pero quizá el caso más interesante entre los romances sea el de "Hermana Marica", clasificado siempre como burlesco sin mostrar el más mínimo asomo de broma o parodia. Entre las letrillas, "Ya de mi dulce instrumento" siempre ha convivido en el grupo de las décimas mudando su especie, ya burlesca (en Vicuña y Hoces), ya satírica (en Chacón), aunque ya aparece bajo el marbete "letrilla" en la docena parte del Romancero general (f. 402r) y en la Segunda Parte del Romancero General y Flor de diversa poesía (f. 78v). Y cuando la letrilla equivoca el referente (“Arroyo, ¿en qué ha de parar?”, 447) da lugar a debates sorprendentes (véase nota 70). Entre los poemas en endecasílabos también hay desacuerdos. El ms. B87-V3-10 B. March inscribe como líricas las canciones "Verde el cabello undoso" (ff. 159 r-v) y "En roscas de cristal serpiente breve" (ff. 160v-162r) aunque ambas perseveran en ser heroicas; la primera (165) en los mejores testimonios impresos y manuscritos, incluido Chacón, y la segunda (223), en gran parte de los manuscritos. Más frecuente es el intercambio de lo lírico con lo amoroso, incluso en Chacón. En la canción "Donde las altas ruedas" (114), Vicuña, Hoces y Chacón aprecian lo segundo en tanto que los mss. Faria (2892 BNE, f. 68 r-v), B2362 HSA (f. 88 r-v) y B93-V1-6 B. March (f. 83 r-v) perciben lo primero. Entre lo sacro, Chacón (I, 150) intuye madrigal "La vidrïera mejor" (291), pero los impresos y manuscritos lo agrupan entre las letrillas, También hay opiniones distintas para las silvas. Hay tres que entran en Chacón (I, 185-192): "Generoso mancebo" (416), "Perdona al remo, Lícidas, perdona" (293) y "Por este culto bien nacido prado" (352), si bien son consideradas canciones en testimonios antiguos (salvo Salcedo Coronel). Por último, resulta enternecedor apreciar lo lírico de la canción "Tenía Mari Nuño una gallina" (309) -aunque así se inscriba en impresos y buenos manuscritos- cuando Chacón (I, 178-180) y B87-V3-10 B. March (f. 113 v-r) disfrutan de su impulso satírico. El mismo que recorre los tercetos “ ¡Mal haya en que en señores idolatra” (202), como registran Vicuña (ff. 53v-55r), Chacón (I, 141-144), y la mayor parte de los testimonios antiguos, pero no Hoces (ff. 56r-57v), que los ve burlescos, o B87-V3-10 (ff. 163v-165r) que no sabe cómo clasificarlos y los envía al purgatorio de varios.

9 El epígrafe, en su polimorfismo, es un intruso influyente. En el ms. Rennert, por ejemplo, el romance amoroso "Entre los sueltos caballos" muestra una advertencia (filológica): "Este Romance [...] està adulterado i falto". Otros escoliastas prefieren la glosa al estilo de la décima burlesca "Con Marfisa en la Estacada" (401): "A cierto galan viejo, que entrando a veerse con una dama, a quien había pretendido i solicitado, non potuit arrigere, i quedò corrido" o, como ocurre con las espinelas atribuidas (ya vistas) "Pues es lunes, con que empieça", la glosa y la especie: "Son Decimas Satyricas. Hiçolas el Poëta para significar la potencia de los frailes, i la inclinación que les tienen las mujeres". Por último, hay otras notas que no dejan resquicio a la sorpresa. En la letrilla "Qué lleva el señor Esgueva" (149), la aclaración (o comento) es, a la vez, advertencia y glosa: "Hiçola el Pöeta en dialogo para describir las corrientes d'Esgueva, rio que passa por medio de Valladolid, donde se echan todas las inmundicias de el lugar: lo qual trata con elegantes metaphoras, qual nunca otro Poëta antiguo, ni moderno". Véase Carreira, 1998: 112-118.

10 Responde Lectura a Zoilo: "Título llamo yo al nombre que se pone a la obra para ser conocida" (Carvallo, 1997: 283). "Como se sabe, es el nombre del libro, y como tal, sirve para nombrarlo, es decir, para designarlo", asiente Genette (2001: 71). 
venidas de lo referencial a lo denotativo y de lo extensional a lo intensional se encuentra la condición del título.

Es en ese territorio de lo impropio ${ }^{11}$ donde algunos nombres muestran también los vínculos con sus efectos y causas. "Conveniunt rebus nomina saepe suis"12, escribe Gracián en el discurso XXIV del Arte de ingenio, cuyo título, "De los conceptos que se sacan del nombre", anticipa el tópico contemporáneo de la motivación, la causa final (Aristóteles, 2011: V, 1, 1013b), moldeado aquí —imagen feliz - en carne de bestiario:

Es hidra bocal ${ }^{13}$ una dicción ${ }^{14}$, que a más de su directa significación, si la cortan o la trastuecan, de cada sílaba renace una prontitud, y de cada acento un concepto. Alcança el nombre su conveniencia con la cosa denominada (Gracián, 1998: 266).

La cita manifiesta la calidad de la etimología del nombre para sugerir "a más de su directa significación" —esto es, su designación o referencia - un "extra" de denotación "oblicua"15 que - gemmatio imago 16 - ansía ser advertida"

11 El Estagirita afirma que el tópico (o predicable) del propio es lo que "se da sólo en tal objeto y puede intercambiarse con él en la predicación" (Aristóteles, 1982b: I, 102a). Para su desarrollo, véase el quinto libro de Tópicos (Aristóteles, 1982b: 128b-139a).

12 “Conveniunt rebus nomina saepe suis. Nomina cum re consentiant". El aforismo ha sido atribuido a Plinio, pero Gracián, que lo recoge como cita poética, seguramente lo toma de Ovidio. En la Vita nuova, escribiendo sobre una ensoñación con su amada Beatrice, Dante escribe: "con ciò sia cosa che li nomi sèguitino le nominate cose, sì come è scritto: Nomina sunt consequentia rerum" (Alighieri, 1980: XIII, 1).

13 En lo que atañe a Góngora, la suerte de la imagen en la preceptiva barroca está bien expuesta en Egido (1990: 20-23, 37-38 y 43 ss.).

14 En este discurso XXIV Gracián se vale únicamente de nombres sustantivos para ilustrar sus estimaciones sobre el concepto. La espléndida imagen mitológica — una delicia para los interesados en la referencia directa- invita a extender el fenómeno a la frase nominal. El nombre como signo, como "presagio" (Nomen, omen), denota el proceso de retroacción semasiológica por el cual el nombre se derrama en sus conceptos. Algo así debe rondar a Gracián cuando usa "dicción" — especialmente el sustantivo y el adjetivo, miembros privilegiados de la categoría nominal - en lugar de "nombre", término que él mismo emplea en el título del Discurso.

15 La cuestión es pertinente para quienes piensan que la referencia es — “Ungerade Bedeutung”, en palabras de G. Frege- usualmente indirecta. Para el lógico alemán, una expresión contiene un sentido acoplado con un significado (primer reino de la semántica), luego la relación entre la expresión y el significado se sitúa en el segundo reino de la semántica, el sentido (véase Frege, 1962: 51). Es probable que Gracián distinga también dos reinos, el extensional de la "recta significación" encaminada a la sujeción del cabo del referente, y un reino segundo (en que convergen los reinos fregeanos) distinguido por la "prontitud", la agudeza que es el concepto, que no pretende acceder al referente porque su reino - evocando verba Evangelii- no es de ese mundo. La existencia de contextos diagonales resulta de la "oblicuidad" del discurso vía el sentido que procura el concepto, motivo por el que el adjetivo "oblicuo" persigue emparejarse con "recto". La pretensión de ajuste entre el mundo y la palabra se desvanece en el éter de la dianoia, así que la metáfora de la concepción ("renace una prontitud") es apropiada para indicar la nueva representación o quizá (más tentador) un nuevo pensamiento (dianoia), en cuyo caso conviene considerar, à la Chuch, el clásico "pensamiento" como "proposición” (Church, 1973: 345), desprovista de los afeites a que se somete la representación.

16 Del lat. gemmatro. Esta imagen trata de mostrar la analogía en el interior del propio nombre iniciático, que es capaz de reproducirse como yema (gemma) sin la participación de un complementario. El paralelo geminación, de larga tradición retórica —el "sintagma binario no progresivo" (Alonso, 1978: 441-460)—, consiste en emparejar palabras o sintagmas, y no parece en absoluto apropiado para ser insignia de este proceso semasiológico, mucho más interesante.

17 Hay cosas anteriores o posteriores "según la naturaleza y la entidad: así todas las cosas que pueden existir sin otras, pero no estas sin ellas" (Aristóteles, 2011: V, 1019a2). Esta prioridad posee carácter ontológico, de manera que la ousía (sustancia) es anterior a las determinaciones accidentales, pero no es evidente qué es anterior en el caso de las composiciones jocosas y su título, pues sus existencias pueden estar sujetas a la implicación 
La relevancia del concepto como autopredicable ${ }^{18}$ resucita la autoridad de los procesos denominativos en el oficio del editor. El nominalismo conceptualista de la escolástica propone que el género $-\mathrm{y}$ el resto de los tópicos en cuanto predicables (Aristóteles, 1982b: II, 7, 112b25) - sólo existen en el intelecto: "Et talle esse in intellectu universalia habere dixerunt illi qui vocabantur Nominales" (Magno, 1651: I, II, 12). Esta orientación del concepto autopredicable como nombre (Universale est nomen), como palabras dotadas de sentido ${ }^{19}$, a veces roza la herejía en la interpretación cuando se desea anular la realidad de los conceptos generales, como parece indicar involuntariamente Gracián con ese "acento": Universale est vox ${ }^{20}$.

Las dudas de los editores surgen ante la ausencia de un estatuto que sea capaz de ajustar lo diverso en lo particular y, al contrario, lo uno en lo general ${ }^{21}$. En efecto, si el uno es común (luego no es uno, pero tampoco muchos), el universal ${ }^{22}$ de género (entendiendo por "género" la articulación de linajes poéticos) tiene difícil su aprobación racional. La aporía consiste, entonces, en sostener que el género está en uno y en varios a la vez (Bochenski, 1956: 36). El concepto "predicable de género" es el ara donde se sacrifica alguna condición de la realidad, y sus heridas ocasionan con frecuencia tal deriva en la interpretación de la lexis y, por extensión, de la phrasis —o elocutio (Quintiliano, 1999: III, lib. VIII, 1, 1)— que resulta engañosa la articulación de un fenómeno que parece no tener fin: "Casi no tiene $V . m$. frasis que no se pueda entender de catorce o quince maneras", le reprocha Juan de Jáuregui a Góngora en el Antídoto ${ }^{23}$, "una obra consagrada a la denuncia de la oscuridad" (Jáuregui, 2002: 61 y 295).

Es la misma opacidad que deleita a otra clase de lectores. Escribía Dámaso Alonso el pasado siglo:

doble. En efecto, la exigencia de reconocer la oblicuidad del significado es "posterior" a la lectura literal (véanse las notas 31, 44 y 45) pero, aunque sea un axioma, no es seguro que haya necesidad de determinar el tópico (o predicable) del anterior asunto. En este sentido, la cita recuerda el atrevido “¿Qué es ser?” (tò tí ên einai) de Aristóteles. La demanda se presenta como status causae de la definición: "Ya que entre lo propio lo hay que significa el qué es ser y lo hay que no, se ha de dividir lo propio en las dos partes antedichas, y a una se la llamará definición, que significa el qué es ser, y a la otra (...) se la llamará propio" (Aristóteles, 1982b: I, 101b20, 102a y 2011: III, 25-32).

18 El término concepto es conceptual.

19 Véanse las "Glosas a Porfirio" 1521-1523 (Abelardo, 1980: 113).

20 Roscelino, maestro de Abelardo, fue procesado por triteísta. Juan de Salisbury resume en su Policraticus la cuestión desde el nominalismo (traducción mía): "había gente que sostenía que los géneros y especies son las mismas palabras ("voces ipsas") pero esta posición fue refutada y desapareció tras la muerte de su autor" (Salisbury, 1909: VII, 12, 142, 2-4).

21 Las derivas no sólo se producen en las lindes del nombre y, por extensión, en el espacio más amplio del período estrófico (coincida o no con la copla), sino también más allá de la clausura categorial que denotan conceptos como "Obra completa", "Obras en verso", "Todas las obras" (véase la nota 39). Los Cancioneros, las Rimas, las Antologías, las Flores (o, persistiendo en la metáfora vegetal, los Ramilletes) son buena muestra de ello. Sucede, por ejemplo, en las Flores de Pedro Espinosa, de 1605, la puesta de largo de la poesía italianizante de Góngora (33 sonetos y 4 canciones), donde no hay distinción de especie poética, pero parecen existir "motivos poéticos que dan pie al poema que sigue" (Molina Huete, 2003: 389). La divergencia en la interpretación es inevitable: un texto que ya no posee la inocencia de la primera lectura condiciona las siguientes mediante un operador modal de naturaleza temporal que viste el texto con los ropajes de la dicción ajena. El texto literario es vital, abandona su sinceridad cuando es alumbrado y nunca logra la madurez. Siempre se acompaña de un corifeo que, bajo la pretensión de modulación, lo subvierte. Paradójicamente, es este conjunto vocal el que lo reconoce como historia. Véase Culler (1995: 136 ss.).

22 "Lo que es naturalmente apto para ser predicado de muchos" (Aristóteles, 1988b: 17a).

23 Con motivo de los versos 958-962 de la primera Soledad. 
Todo el arte de Góngora puede reducirse a un constante intento de eludir la representación directa de la realidad sustituyéndola por otra que indirectamente la evoque, pero ya nítida, realzada, con especial intensidad poética (Alonso, 1984: 172).

El insigne crítico no deja de lado el oficio poético cuando despliega la relación entre ambas representaciones mediante la metáfora de la "evocación", bella declaración de la inteligencia de una expresión poética como una función entre los mundos que se originan por el hecho de que estos enunciados sean instancias del mundo factual - la mencionada "realidad"- y el valor de verdad a que dichos mundos aspiran.

Este enfoque dual tiene en su contra la lejanía entre los mundos propuestos, seguramente por el grado de abstracción que denota una representación alusiva que los disjunta con la intención última de aunarlos. Como advierte U. Eco (1992: 49):

Para poder explicar el mundo a través de causas hay que elaborar una noción de cadena unilineal: si un movimiento va de A hacia $\mathrm{B}$, ninguna fuerza en el mundo podrá hacer que vaya de $\mathrm{B}$ hacia $\mathrm{A}$. Para fundar la unilinealidad de la cadena causal es necesario haber admitido algunos principios: el principio de identidad $(A=A)$, el principio de no contradicción (imposible que algo sea $\mathrm{A}$ y no sea $\mathrm{A}$ al mismo tiempo) y el principio de tercero excluido (o A verdadero o A falso y tertium non datur).

Por otro lado, la disjunción es el asiento del juicio apofántico, molde de la verificación en el mundo factual, y resulta paradójico que la representación de una "realidad" indirecta - luego una instancia de mundo — pueda a su vez modificar las condiciones de verdad de otro mundo, el factual, mediante su nueva representación, que ahora es "ya nítida" debido a la "especial intensidad poética". Hay aquí un enfoque recurrente del hecho poético como creador de una "realidad" - concepto cuya intimidad tautológica va más allá de lo autopredicable ${ }^{24}$ - que funciona bastante bien fuera del horizonte hermenéutico pero que es insalvable con la mirada puesta en él. En efecto, si el relato de una parte del mundo factual (aquel en que se encuentra el ser del título) funciona con las maneras de un palimpsesto - esto es, modificado por otra realidad- y en el proceso adquiere textura - cualidad - , surge dentro de este mundo factual un "cartapacio de mundo" - ucronía factual con textura de mundo poético - cuyas cuadernas parecen arruinarse en la inquietud del colector por asegurar, mediante la asignación de un título, la "cadena unilineal" de la que habla el crítico italiano.

Hay cierta ensoñación creacionista en una interpretación cuya naturaleza paradójica permite, sin embargo, la íntima convivencia con algún tipo de logos derivado de la exégesis tipológica de raíz escolástica. La ilusión se ampara en la voluntad de trascendencia inherente a una hermenéutica que busca su élan en la tropología de la inmutabilidad. Los significados escatológicos (o anagógicos) surgen en la interpretación por la presencia inteligible de alguna presuposición modal de carácter intencional que bloquea la parte temática ${ }^{25}$ de la semejanza expresada por la analogía,

24 Estos tres principios de la lógica clásica son epítome de lo que se entiende por "tautología”. La paradoja consiste en atribuir al objeto la propiedad de "ser real", al fin y al cabo, la expresión-predicado del concepto "realidad".

25 El polo formado por los miembros A y B de la analogía. Véase Perelman y Olbrechts-Tyteca (1989: §§ 82-88) y Reboul (1986: 182). 
nada menos que el mundo factual al completo. Este milagro realizado con palabras tiene un nombre: alegorismo ${ }^{26}$.

Pero todavía se puede salvar, en lo que afecta al título predicable, ese tipo de dualismo de la representación. Sin perder de vista que el texto es único y no puede huir - en pasiva - de sí mismo, una perspectiva capaz de sustituir una realidad por otra mediante un simple desvío en los rituales de la representación admite que ambas realidades (los poemas del cartapacio y los títulos de género y especie del colector) concurran si y solo si se evocan. Los modos en que se consuma dicha función de "evocación" afecta, por un lado, a la lectura del texto poético y, por otro, a la figura "factual" título-texto, paradigma del dualismo prototípico derivado de la figuración icónica ${ }^{27}$ de raíz supuestamente conceptual impuesta en la edición. La función de "evocación" se adivina relevante en la fábrica de un modelo mostrativo para la suscripción del título.

\subsection{Asimetrías: opacidad y causalidad}

Originado en ese logos excéntrico que debilita el mundo fingido - libre de los índices de espacio y de tiempo, entre otros referentes - mediante los estigmas del concepto, el instrumento que vivifica la nueva representación sin acudir a la agobiante pauta de verificación de la semántica se sitúa en la elíptica sobre el mundo factual sin intervenir en el eje de rotación de este, pero modificando de algún modo su naturaleza. Maurice Molho expresa con resolución algo semejante por medio del argumento práctico: "Góngora opère la transmutation poétique de l'univers au moyen du concept", al tiempo que marca el camino de su consecución via conclusión del silogismo: "il faut apprendre à le lire avec les yeux d'un Gracián"28 (Molho, 1977a: 119). Mercedes Blanco, comentando a Tasso, afirma que "ningún objeto puede representarse si no es por mediación de los concetti" y concluye que "mirar a Góngora desde Tasso es una apuesta tentadora [...]" (Blanco, 2012: 299 y 85).

Pero también inquietante. En la persistente sinécdoque de la visualización yace un operador "de interpretación diferida" que opaca la articulación de los ámbitos en que Góngora muestra sus desafectos al mundo factual y sus máscaras lo secundan. Por otra parte, la lectura como conceptualización carece de la inflexión necesaria para acercar el concepto a su objeto (en sentido escolástico o eidético). El carácter de "objeto" conceptualizado se percibe en la edición que asienta sus didascalias en fórmulas binarias que disgregan el orbe originario - gemmatio mundi- en los territorios posibles de lo verdadero y lo falso ${ }^{29}$, empobreciendo tanto el mundo donde

26 "Littera enim occidit, Spiritus autem vivificat", sentencia Pablo en el latín de San Jerónimo (Biblia Vulgata, 2002: 2Co 3, 6). En el Rotulus pugillaris, Agustín de Dacia, seguidor de Casiano y Agustín, expresa en la brevedad de un dístico los cuatro sentidos clásicos (literal, alegórico, deóntico y escatológico) de las Sagradas Escrituras: "Littera gesta docet, quid credas allegoria, / Moralis quid agas, quo tendas anagogia" (Walz, 1929: 256). Véase Vattimo (2006: 22).

27 No de otra manera se explica la existencia de los peritextos (epígrafes, prefacios, intertítulos, notas o "dedicatorias") y, especialmente en la edición más actual de Góngora, de los epitextos privado (cartas y otras correspondencias) y público, como las “censuras” o “calificaciones”. Véase Genette (2001: 295-348).

28 La traducción à la lettre en español es desafortunada (véase Molho, 1977b: 62). La propuesta del crítico francés la recoge Blanco (2002: 325 ss.).

29 La bina que soporta el concepto de "verdad" se expresa, como "función característica", en términos que denotan oposición complementaria (verdadero/falso, 0/1, etc.). Este cierre categorial sólo encuentra la salida si, como en 
habita el colector como la "prontitud" 30 que anhela la especie poética. Al final, la porfía de estas realidades degradadas que se retroalimentan por medio de la función causal $^{31}$ acaba desorientando al receptor. Confundido tanto en los espacios polifónicos (poeta y colector) como "poligráficos" (título y texto) de la metalepsis, no encuentra el postigo hacia un espacio y un tiempo órficos, alejados por causa de la penosa figuración en torno al título.

Sucede, por ejemplo, en una de las ceremonias más frecuentes en la poesía burlesca y satírica de todos los tiempos, que consiste en engastar nombres y apodos de esta tradición en el aderezo de tipos y personajes, con el auxilio o no de los cimientos de la rima. La mano retórica — nada ingenua, hábil- rubrica estos nombres de "burlescos", "irónicos", "ridículos" o "satíricos", pero con ello confina sus pasos ficcionales a la menguada parroquia de lo jocoserio, donde la calidad de sus ropajes - acceso único al modo del personaje - se degrada por el carácter que imprime el $\operatorname{cognomen}^{32}$. El manto de jocosidad ${ }^{33}$ con que las rúbricas lo abrigan le facilita - es su fortuna- el temple necesario para alcanzar el rango de lo satírico-burlesco, condición que parece incluir en diverso grado un contenido significativo comprendido en el devenir ficcional del personaje. Hay algún tipo de mención de "especie" que reduce el nombre a su causa final ${ }^{34}$ en tanto que le provee de un valor firme, constante, que bloquea la interpretación y que fuerza a leer cualquier nombre en un poema burlesco o satírico asociado con una causa final acreditada en la fisiología de la mueca o la risa ${ }^{35}$.

la "paradoja del mentiroso", el par, a su vez, se doblega ante un nuevo predicado de verdad, del tipo "(A es 0) es 1". Para la gemmatio, véase la nota 16.

30 Omnipresentes las palabras de Gracián.

31 Otro de los usos aristotélicos de prôton ("anterior") se caracteriza "por no ser reversible y por la implicación de existencia" (Aristóteles, 1982a: 14a26; véanse las notas 17 y 44). En nuestro ámbito, las décimas, romances, letrillas o tercetos (existentes) son causa "anterior" del título de género o especie, así que no hay reciprocidad entre ellos.

32 "La clasificación de un poema como lírico o como amoroso o burlesco o satírico, las anotaciones marginales, incluso las variantes de cada composición nos hablan de formas y de modos — de modas, a veces- de lectura" (Pérez Lasheras, 2000: 452). Véase la nota 34.

33 En torno a la preferencia de Góngora por los adjetivos "jocoso" y "burlesco", hay que agradecer a A. Chacón su claridad: "El nombre que se da de Burlescas à las que lo son, va (como lo demas) expuesto à las censuras de los que, por Latino, quiçà admitieran menos el de iocosas. Pero ni nuestra lengua tiene otro adjetivo desta significacion, ni Don LVIS estrañò este en los exemplares que permitiò de sus Obras" (Góngora, 1991: Advertencias). En los tercetos “¡Mal haya el que en señores idolatra...!” (202, vv. 23-24), el poeta declara su doctrina poética "contiene la república volante / poetas, o burlescos sean o graves". El uso de "jocosidad" no tiene más fin que evitar el impulso en la interpretación que, irremediablemente, ejerce el deslucido doblete "satírico-burlesco", introducido en el siglo pasado (véase Alonso, 1976: 528).

34 Es innegable que la disposición del nombre en un poema se asocia directamente con un sentido. Las ediciones de Góngora que siguen a Hoces, incluso las de Foulché-Delbosc (Góngora, 1921: n. ${ }^{\circ}$ 497) y Millé (Góngora: 1932: n. ${ }^{\circ}$ XXV), truecan el nombre del pastor porfiador de la letrilla “Arroyo en qué ha de parar", Carillejo — tan usual en la poesía pastoril- por el parlante "Carrillejo". Primera entre las "burlescas", el error llevó al desvarío a algunos defensores del poeta Luis Carrillo y Sotomayor que, deseosos de erigirlo como su rival natural, vieron aquí su oportunidad. L. Astrana Marín publica, entre enero y febrero de 1927, una serie de artículos en Los Lunes de El Imparcial, titulados "Los orígenes del gongorismo...", donde censura al cordobés: "Fue tan infame Góngora en su existencia, fue tan en todo momento el ángel malo de Carillo, que antes de fallecer este y de robarle su tesoro literario, el racionero insultó sus blasones en aquella letrilla: Arroyo en qué ha de parar [...]" (apud Jammes, 1963: 150). Véase Rojas, 2011: 51 ss.

35 En la Censura del Padre Pineda a la edición de Vicuña, publicada íntegramente por D. Alonso en su prólogo a la edición facsímil, se mezclan las instancias textuales y extratextuales. El censor da a entender que el libro habrá causado, por razones diversas, estimación “entre los hereges, a quien ya avrá llegado este libro por manos 
Estos motivos (o "causas finales") son parte del contenido intencional del que no puede sustraerse el editor o amanuense en la asignación del título "como retroalimentación", asimetría que no concierne a la iconicidad bipartita integrada por la inscripción y el texto. En este sentido, no sólo se revela como impropio el dualismo extensional, sino que el carácter intensional del concepto, ese tercer componente que parece clausurar la bina propuesta por la semántica veritativa, opaca la función entre las partes.

\section{Simetrías: predicables y epojé}

Parece necesario, para lo intencional funcional del recopilador, un compromiso entre el conjunto extensional de coplas que participan de su deixis y el vasallaje a la intensión conceptual que se descubre en ese "culto Poëta cisne en los concentos, ${ }^{36}$ Aguila en los conceptos; en toda especie de Agudeza eminente" (Gracián, 1998: $\mathrm{V}, 157)$ que es Góngora. El recopilador (contrariamente al lector no autorizado) se encuentra ante un palimpsesto en que palpitan dos textos. En el primero, la calidad de los significados insinuados, aquellos que intentan desviarse de la directriz que supone la significación monótona mediante la traza de una parábola, se origina en el carácter de su curvilínea. En el caso del nombre asociado a un concepto, la traza germina en lo hondo de ese signo, pero con el aliento de la sugerencia (suggerere, "colocar debajo"). En ese camino más largo - por corvo- el foco y la directriz se sincronizan en la lectura en modulación permanente pero asimétrica.

Por su parte, el título, preñado de conceptos (predicables) y causalidades, recorre la parábola sin compromiso alguno con el nombre del concepto debido a que no existe modulación entre lo serio y lo honesto que satisfaga una perspectiva del género como concepto "sin su nombre". Ahora el foco es un lugar geométrico ${ }^{37}$ equidistante con la directriz. Ni el compilador ni el lector disponen de una tradición que diferencie el genus turpe ${ }^{38}$ del honestum, por lo que el decoro medular con que letrillas, décimas o romances satíricos o burlescos (y otras especies y formas métricas) se

y curiosidad de los que andan entre nosotros tan atentos todos a murmurarnos [...]. Porque aunque este libro no sea del todo lascivo, mas porque el autor sólo tuvo su famosa eminencia en lo lascivo y picaril, verde y picante, por esta sola materia y título es leído y buscado, como si de esto solo escriviera, y assí haze tanto daño, y se deve reputar como si exprofesso oviera escrito de sola ella" (Góngora, 1963: XXX-VI). "Pero seamos honestos, estas censuras no van del todo desencaminadas, pues fue el propio Góngora el que jugó siempre a confundir y borrar fronteras entre los papeles discursivos. De hecho, las acusaciones del padre Pineda hacen menos hincapié en las obscenidades que en el hecho de que se traten temas religiosos y de que el hablante de los poemas se presente a sí mismo como persona de iglesia, cosa que era el Góngora real”, interpreta acertadamente Luján Atienza (2006: 43).

36 "une harmonieuse conjunction de vocables" (Molho, 1977a: 119). En este caso, la traducción en español de “vocable" por "palabra” oculta las calidades fónicas. Véanse Molho (1977b: 62), Carreira (1988: 47 ss.) y la nota 28 .

37 La parábola como imagen no es extraña en la escritura gongorina. La expresa por medio de la metáfora de la media luna (el toro) en la Soledad primera (v. 3) y en el soneto "Salí, señor don Pedro, esta mañana" (268). Últimamente se han estudiado los vínculos entre la reconocida coloración retórica del universo gongorino y la figuración geométrica de las parábolas, rectas, elipses, arcos y esferas (Capllonch y Micó, 2013: 251-252).

38 La cuestión puede formularse así: "podemos reconducir, creo que provechosamente, la discusión sobre intenciones acudiendo al concepto retórico de decorum, o aptum, el mecanismo regulador de todas las instancias discursivas" (Luján Atienza, 2006: 41). 
disponen en el cartapacio es consecuencia de la autolisis actitudinal del compilador. Sin duda hay una pugna entre sus funciones social (docere) y privada (delectare) que beneficia a la primera en ediciones completas, ramilletes o antologías.

Parte de la cuestión radica en reconocer el universal en la piel de la realidad fenoménica. Si, como se ha visto, la parte de la manifestación queda dentro de la deóntica del recopilador — no de su saber-, el contenido intencional del icono resultante busca la simetría entre las que intuye décimas o letrillas y el universal que desconoce: la diligencia en la adjudicación de un título predicable se somete al modo de colección ${ }^{39}$ a que se sujeta la labor del compilador, que elige ahogar la voz sugerida del poeta con el hilo áspero de la evidencia icónica.

Una salida digna para esta función tópica del compilador reside, siguiendo a Boe$\mathrm{cio}^{40}$, en revocar el vínculo ontológico entre el género y la especie, invalidando la substancia de estos universales simples. Para templar el afán de trascendencia que denota este adjetivo, es posible diluir el universal de género en otro universal para obtener un universal compuesto ${ }^{41}$ que acceda a clausurar temporalmente la realidad fenoménica, como sucede en el teatro, donde se salva la simultaneidad y la unidad porque "es común a todos los presentes" (Boecio, 1906: 1. 10. 18, 162). La epojét hace posible suspender los universales de género y de diferencia o propio (no el de especie), en tanto que su solución (universales "compuestos" de la definición ${ }^{43}$ o de la descripción) se realiza via el tiempo ${ }^{44}$.

\subsection{Dimensiones}

El aspecto que presenta la resultante de la función de predicación del colector (figura título-texto) denota lo indivisible de los espacios dedicados a la colección (los poemas)

39 "en lo que toca a la poesía de Góngora, no se puede razonar por colecciones de obras completas, sino por poesías sueltas, y a veces por estrofas o por fragmentos" (Jammes, 1980: 22).

40 Boecio, en el primer apartado de su segundo comentario a la Isagoge de Porfirio (en la edición canónica de S. Brandt) trata las cuestiones sobre los universales que Porfirio evita, si subsisten o si son inteligibles, o si existen separados de lo sensible o concuerdan con ello (Boecio, 1906: 1. 10. 1, 159).

41 "La definición consta de género y diferencia" (Aristóteles, 1982b: I, 103b15). Véase la nota 17.

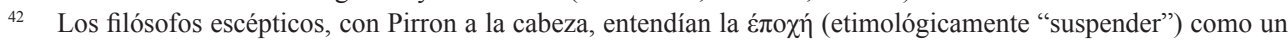
estado psicológico —diríamos hoy— "intencional" resultante del juicio de equidistancia ante dos proposiciones igualmente defendibles, pero opuestas o contradictorias entre sí, lo que acaba, irremediablemente, en una duda universal. E. Husserl limita la universalidad de la duda expresada mediante la metáfora del paréntesis: "Esta limitación puede formularse en dos palabras. Ponemos fuera de juego la tesis general inherente a la esencia de la actitud natural. Colocamos entre paréntesis todas y cada una de las cosas abarcadas en sentido óptico por esta tesis, así, pues, este mundo natural entero, que está constantemente 'para nosotros ahí delante', y que seguirá estándolo permanentemente, como 'realidad' de que tenemos conciencia, aunque nos dé por colocarlo entre pa-

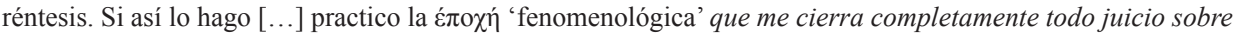
existencias en el espacio y en el tiempo" (Husserl, 1985: 73-4; las cursivas son mías).

43 El lugar común aparece ejemplificado en Aristóteles (1990: 1398a) y Quintiliano (1999: V, 10, 36). El primero la incluye entre los cuatro predicables: "todo viene a reducirse a cuatro cosas: propio, definición, género y accidente" (1982b: I, 102a).

44 Una vez distinguidos los sentidos ontológico y causal del tiempo no histórico en Aristóteles, parece ineludible establecer la relación entre lo "anterior" y el universal (Aristóteles, 2011: V, 1018b14). Para el Estagirita hay un último sentido de "prioridad" con dos significados: "según la noción (el concepto) los universales son anteriores, mientras que los individuos lo son según la sensación" (1018b29-34). Esta diferencia entre conceptualización y percepción muestra las maneras de conocer según la "prioridad". Epistemológicamente, el universal es anterior a lo individual si atendemos al concepto; por el contrario, si atendemos a sensible, lo particular es anterior al universal. 
y a la voz del recopilador (el título predicable), pero adquiere un sentido de prominente bidimensionalidad si el tiempo ${ }^{45}$ puede operar en el interior de dicho espacio.

La figura del tablero ${ }^{46}$ ilustra este fenómeno en el juego abierto de la ficción, donde las piezas léxicas, en el espacio-tiempo de la literalidad, se agitan en las casillas bautismales (las que ocupan los espacios iniciales) con las maneras de un prisma que refracta, descomponiéndola, la luz de las celdas más tempranas. El prisma, que anhela una fuente de luz que filtrar, refleja estos significados transparentes coloreando ${ }^{47}$ (luego modificando) tanto los estantes del sintagma (el verso) como, por "efecto dominó", los del paradigma (el período). Con ello se hace acreedor de otro espacio-tiempo relativo al mundo posible donde palpita el nuevo sentido. Hay cierta emoción ${ }^{48}$ en este espacio engendrado en el tiempo, un movimiento hacia afuera que, entre otras contingencias, tolera que florezca la controversia interna, permitiendo así saborear los frutos de la poiesis edénica escogidos del árbol de la interpretación y engendradores de enarjéia, una curiosa reacción emocional consistente en abrir los ojos y la mente a la vez.

En estas aperturas ficcionales, la facultad divisa del tablero se funda en la precisión del espacio de las casillas y en la vaguedad del sentido, enarjéia que legitima la "prontitud" conceptual y la función causal aplicada, esta vez, a lo jocoso ${ }^{49}$. Como recuerda Pedro Díaz de Ribas, comentarista de Góngora, el hecho de no distinguir estas "trasposiciones" - figura y tropo- " "no será culpa del poeta galán y levantado, sino de el floxo que no quiere construirlas y entenderlas" (s.f: f. $81 \mathrm{v})^{50}$.

45 Esta dimensión aparece ya en el estructuralismo. Dejando de lado una hermenéutica interpretativa basada en el receptor, M. Rifaterre se ocupa del desarrollo de las respuestas del lector e insiste en la conducción de esa reacción por la secuencia del flujo temporal (1966: 233 ss.). En la Escuela de Constanza el índice de tiempo es tenaz: "las dos partes de la relación texto-lector (es decir, el efecto como momento de la concretización [sic] del sentido, condicionado por el texto, y la recepción, como momento condicionado por el destinatario) tienen que ser diferenciadas" (Jauss, 1986: 17). Por otra parte, "el sentido del texto es un acontecimiento en la lectura, siendo esta anterior al significado atribuido en la obra" (Iser, 1987: 46). U. Eco anticipa algunas de las conclusiones que se están apuntando aquí, como el enfoque gnoseológico del universal y la elección del icono en el modo de colección: "1) las obras "abiertas" en cuanto en movimiento se caracterizan por la invitación a hacer la obra con el autor; 2) en una proyección más amplia (como género de la especie 'obra en movimiento'), hemos considerado las obras que, aun siendo físicamente completas, están, sin embargo, 'abiertas' a una germinación continua de relaciones internas que el usuario debe descubrir y escoger en el acto de percepción de la totalidad de los estímulos" (Eco, 1979: 44).

46 "Y otros juegos como el ajedrez con sus 64 cuadrados blancos y negros que [...] configuran un mandala sobre la totalidad posible de los movimientos y transformaciones" (Vicente García, 2006: 110, nota). Incluso "la presencia de tableros de juego sacralizados al ser insertados en las catedrales está bien documentado, y probablemente no pasara del todo desapercibida a Góngora" (114, nota). En mi caso, la metáfora del tablero carece de valor simbólico.

47 "Coloración" (Fahrbung) o "iluminación" (Beleuchtung) denomina Frege a las diferencias de significado que no son pertinentes para determinar el valor de verdad de un término o expresión (Frege, 1996: 30 y 1962: 52 ss.). La metáfora cromática es más productiva como componente de la alegoría del tablero. El signo lingüístico puede ser empleado, como ejemplar, de manera discreta, pero es en la composición del tejido sémico donde el prisma adquiere su valor, reflejándose — de ahí la figura de la casilla— en los signos que estén orientados de manera conveniente. Pero esta orientación no viene dada en exclusiva por la ocupación del espacio de las celdas contiguas, sino también por la disposición del signo para la emoción, es decir, la propiedad de encontrarse en un cierto estado (análogo al "estado mental") asociado a algún tipo de modo.

48 No se habla aquí del significado "emocional" de las palabras, sino de que "significado léxico" es la frase descriptiva al uso (sin negar la posibilidad de que haya otras) de la facultad de términos y frases (en cuanto ejemplares, no tipos) de manifestarse, como objetos, fisiológicamente.

49 La función causal (función del pathos) opera, como decía antes, sobre el nombre burlesco y el lector.

50 Hay un texto mejor de los Discursos apologéticos... en el ms. 3726 BNE (ff. 72-221). 
Por su parte, el icono bipartito parece bloquear cualquier apertura en los niveles ficcional o sensual a causa de la suspensión de la interpretación exigida por el topos de predicación del colector, al fin y al cabo un icono predicable de edición.

\subsection{Funciones}

Desde su nacimiento, la titulogía ${ }^{51}$ ha propuesto, como parte de la investigación general sobre la paratextualidad, diversas funciones para lo que aquí se denomina "título predicable". Adjetivos tan dispares como "seductora", "global", "designativa", "temática" o "remática" 52 vienen a cubrir dicha demanda, pero sólo algunas de ellas secundan con acierto la propuesta inicial.

En primer lugar, la denominada aquí "función causal", en cuanto que persuasiva ${ }^{53}$ $-\mathrm{y}$, por lo tanto, abierta a la respuesta del intérprete-, resulta ineficaz para explicar la naturaleza del título predicable, en principio intransitiva. Por otra parte, algunas propuestas en torno a la relación del título con el contenido global del texto son lo suficientemente vagas como para no ahondar en ellas ${ }^{54}$, aunque la razón de que esta función no sea eficaz radica en que el predicable se sitúa antes, y el contenido después, en armonía visual con el icono bipartito. Se trata de una cuestión de "reflexión tópica" respecto del conjunto de poemas sobre la que se volverá más tarde.

La denominada "función designativa", defendida por Genette para la sátira ${ }^{55}$, no actúa en la dirección "título-mundo extensional" porque el conjunto de décimas satíricas del cartapacio (por ejemplo) es un subconjunto de todas las décimas satíricas existentes. Si así no fuera, dicho subconjunto tendría su particular nombre propio "designador" (el título privativo), común a la vez para todas las demás décimas incluidas (de nuevo) ellas mismas como miembros del conjunto. El hecho de poseer $a$

51 (o, con menos éxito, "titulística") es la disciplina que se dedica al fenómeno de la titulación. El término aparece en el subtítulo del artículo "La Fille abandonée et La Bète humaine. Éléments de titrologie romanesque" (Duchet, 1973: 49).

52 J. Besa Camprubí sin referirse directamente a ellos, parece incluirlos entre los que denomina "neutrals y "contrastius" ("no neutrals"), pero no mejora las distinciones previas (Besa Camprubí, 2002: cap. 5).

53 La función “de seducción del público" (Genette, 2001: 68) es válida solo en el caso de que el lector, motivado por el contenido de algunas composiciones, busque el título predicable como si fuera - evocando a Quevedouna "aguja de navegar cultos" en la edición física. Esto es posible en el manuscrito Chacón, que posee un índice de contenidos "según los géneros de sus versos. Si bien en cada vno van subdiuididas las materias, i colocadas en el lugar que parece se deue a cada vna" (véase la nota 4), pero no ocurre lo mismo en la edición de Hoces (que propone, antes de la foliación, un "índice de las poesías que en este libro se contienen") y mucho menos en la de Vicuña, sin ninguna clase de índice. En el caso del manuscrito Chacón, la función del título predicable puede variar (y con ella el carácter del icono) si el lector lo busca después de la lectura poética.

54 "La relación entre un título y un 'contenido global' es eminentemente variada, desde la designación factual más directa (Madame Bovary) hasta las relaciones simbólicas más inciertas (Le rouge et le noir), y depende siempre del gusto hermenéutico del receptor" (Genette, 2001: 69). Más tarde, reconoce la dificultad de volver a introducir entre ambas funciones ("designativa" y "de contenido") los títulos subjectaux y los objectaux (Hoek, 1981: cap. 3). Al final acaba denominando temáticos a "los títulos que indican, de la manera que sea, el 'contenido' del texto [...]: los otros podrán ser calificados de formales y, muy a menudo, genéricos" (70). El problema es que no sabe "si será necesario considerar estos dos tipos de relación semántica (entre título y texto), como dos funciones distintas o como dos especies de la misma función" (71). Todo esto le conduce a "rebautizar temáticos a los títulos ‘subjetuales' de Hoek, y remáticos a los ‘objetuales”” (70). Las cláusulas en cursiva son mías.

55 La función designativa, rescatada por Leo H. Hoek (1981: 6 ss.), "no se cumple rigurosamente siempre, ya que muchos libros comparten el título homónimo [...]; pregunte a un librero si vende las Sátiras, y no obtendrá de él más que una pregunta a cambio" (Genette: 2001: 68). Por otra parte, como denomina remáticos a los "objetuales" de Hoek (véase la nota anterior), no es posible recuperar la rematización como sinónimo de designación. 
la vez nombres propio y común pone en cuestión el principio de identidad, y liquida el título predicable como argumento de la función designativa.

Aunque dicha función (con su variante "remática") no parece útil tal como se encuentra formulada, aporta dos condiciones necesarias: el enlace entre el título del recopilador y el cartapacio, por un lado, y la anticipación temporal y espacial del rema, vivificado con la voz autorizada del editor, pero contraria al modelo secuencial de la aserción lógica del enunciado. Sería oportuno introducir en este momento algún tipo de rúbrica, explícita o no, que reconozca la naturaleza bimembre del icono.

\subsection{Acercamientos}

Parece que sí existen funciones en este ámbito que afectan sólo al título. En los apartados anteriores han aflorado una posible función "didascálica" (sin virtuosismos morales) o una función instrumental "índice" que permite navegar por la edición o el manuscrito. En cualquier caso, ninguna se ocupa de la cuestión tal como viene formulada en la introducción.

Lo que aquí se viene exponiendo es la existencia de una figuración icónica sensible (no conceptual), dispuesta en el cartapacio en dos áreas visualmente dependientes, y donde el título predicable, sobrepuesto - luego anterior-, ocupa el espacio del primer argumento de un modelo predictivo fundado en la anticipación de la creencia. Sin duda existe aquí un emparejamiento tópico construido en torno al tiempo y la cualidad (en el sentido de la "ucronía factual" que aparecía en el primer apartado) que reclama (apartado segundo) algún tipo de esquema bidimensional.

Una de las funciones que sí afectan al icono es la de "evocación" (apartado primero), que parece asimilar la función "de seducción" pero sin la intencionalidad del pathos. Peregrina a la respuesta del intérprete, dicha función evita el dialogismo afectivo que impide cualquier acercamiento lógico a la figuración icónica. Además, la función de "evocación" (seducción "sin" pathos) demanda una rúbrica que le conceda ese estatuto privilegiado que le faculte para allegar, además, una posible función remática, única que responde a la anticipación del predicable. Aquí se ubica también la cuestión secundaria acerca del universal compuesto, que parece tener salida dentro la descripción o la definición (apartado segundo), formas de la proposición analítica de la que la figuración bipartita, merced a la integración de sus miembros mediante la función de "evocación", es un buen ejemplo.

Pero nada es posible sin la suspensión de la interpretación. De hecho, la función de "evocación" sólo se da en el ámbito de la ucronía, es decir, dentro de la epojé (apartado segundo), sin la cual le monde renversé del icono bipartito no puede explicarse.

\subsection{Función clística y sentido}

Si lo central de la epojé es su carácter absoluto (ante los juicios de existencia en el espacio y el tiempo), debe hallarse alguna huella de la realidad "en que la epojé es", alguna marca que acredite la figura icónica sin que genere un juicio sobre su existencia. Obviamente, el bloqueo del juicio no es intencional por parte del recopilador debido al carácter convencional (luego real) del icono. Es este carácter convencional lo que debe dejar una señal no explícita. 
Propongo aquí, como marca no explícita, un "signo de inscripción” que confiera a la figuración "título-texto" el rasgo de iconicidad ${ }^{56}$ espacio-temporal preciso para que ambas partes se ubiquen tipográficamente en vertical. Contrariamente a lo que, por ejemplo, sucede en un cuadro, donde un "signo de suscripción" 57 firma al pie (subscribere) lo que se presenta previamente, el "signo de inscripción" (inscribere) permite rubricar antes (más arriba) lo que se presenta después (más abajo). El "signo de inscripción" supone el icono bipartito, pero especialmente la clausura de la aserción, entendida aquí (en lectura no dividida) como el fin de la primogenitura del título como subiectus, como asunto del que $e^{58}$, posteriormente, va a tratarse.

Siguiendo a Richard M. Hare, llamo clística $^{59}$ a la función que desempeña este "signo de inscripción". Entre sus virtudes podemos encontrar un acercamiento al sentido del icono, entendido como esa "materia oscura" cuya forma no podemos descubrir pero que es, obviamente, convencional. En el icono "título predicable-texto" el sentido está cercano al "modo de presentación” fregeano (Frege, 1962: 51), la "manera de" darse el referente (décimas, romances, letrillas, etc.), sin mucho más aderezo.

Esta relación silenciosa ${ }^{60}$ posee una fenomenología ciertamente particular, como se ha visto, aunque más interesante aún es el hecho de que la inhabilitación del recopilador (y, como cabo, del lector ${ }^{61}$ ) viene dada por el sentido del icono, lo que niega cualquier disputa entre los miembros adscritos a la enunciación poética. Curiosamente, la retórica ya previó las "causas sin estado", sin controversia, y las denominó asystata (Cicerón, 1997: I, 6, 10 y 2002: III, 28, 109). Algo parecido (sin llegar a ser una "causa") sucede con el icono: se toma como axioma de un par textual que se relaciona ("dialoga") 62 sin réplica, lo que parece enfrentarse al principio de no contradicción.

56 En Martínez García (2015: 55-56) se reflexiona sobre este "rasgo de iconicidad” pragmático inspirado en los indéxicos ocultos.

57 "Because the word assertion can be confusing, I propose now to abandon it, and speak instead of a sign of subscription" (Hare, 1989: 25 ss.)._

58 Al fin y al cabo, una interpretación comprometida con una creencia de re, es decir, sobre la cosa que es, espacialmente y temporalmente, el título como parte inseparable del icono.

59 En su análisis del lenguaje moral, Hare introdujo el trinomio frástico, trópico y neústico para expresar los tres niveles de la enunciación: el contenido descriptivo, la clase de acto de habla y el compromiso del hablante con lo dicho (Hare, 1975: 27-8). Más tarde, sumó al trinomio (aunque sin éxito) el clístico: "I now come to the third and last particle on my list, which I shall call the sign of 'completeness' or 'clistic', from the Greek word for 'to close'. The commonest clistic in ordinary languaje is the full stop" (Hare, 1989: 32).

60 Genette ha aplicado el "silencio" a la transtextualidad: la función de intertextualidad (un texto en otro), paratextual (un texto con sus "epitextos") y la architextual, que "se trata de una relación completamente muda, que, como máximo articula una mención paratextual (títulos como en Poesías, Ensayos [...]), de pura pertenencia taxonómica" (1989: 13).

${ }_{61}$ Si aceptamos la propuesta, se hace difícil suscribir (exceptuando la cláusula inicial) las palabras de Genette: "En último término, la determinación de estatuto genérico de un texto no es asunto suyo, sino del lector, del crítico, del público, que están en su derecho de rechazar el estatuto reivindicado por vía paratextual” (1989: 13).

62 La falta de "diálogo" se produce entre las distintas instancias de la enunciación, no en la dispositio del icono, donde sí hay transitus entre la aparente propositio (sentencia) y la expositio de los poemas (véase Quintiliano, 1999: 76-78 y la nota siguiente). 


\subsection{Proporción y logos}

En cuanto "estructura", todo icono apetece la proporción de sus miembros y detesta asimetrías entre los contenidos de las partes. Un mecanismo sencillo de consecución de sus vínculos consiste en establecer patrones figurales de base analógica que sean susceptibles de recibir — semántica y pragmática amalgamadas - aserciones analíticas cuya ilación íntima codicie la expresión de stasis que consuma el éxito de un modelo de "monotonía persistente" ya inscrito en las thései de Hermágoras ${ }^{63}$. Un título predicable como el de "sonetos satíricos" (o "burlescos") suscrito por los poemas que le siguen es la fórmula de una suerte de correspondencia que pretende el principio de identidad. Algo que no se cumple en los títulos de contenido global "temático" como en Soledades ${ }^{64}$, donde la enigmática función "de seducción" ${ }^{65}$ asoma en los niveles más profundos de la ficcionalidad. $\mathrm{O}$ en los títulos de contenido designativo como Fábula de Polifemo y Galatea, donde fascinan los nombres mitológicos que merodean lo ficcional pero ahora identificados de manera laxa con el decorum del tema "no global" (Fábula). En cambio, hay títulos que pretenden correspondencias firmes, sujetas al aptum al precio (voluntario o no) de sacrificar la función "de seducción". Es el caso de la Comedia de las firmezas de Isabela o la Comedia del doctor Carlino, donde los nombres propios carecen de impronta ficcional, pero la adquieren - como carácter- mediante el relato de sus atributos propios o accidentales (firmezas, doctor) y la designación del tema "no global" (comedia) ${ }^{66}$, pero aptum.

En todos estos casos es Góngora quien establece las correspondencias que nutren la bifronte de clérigo y de poeta, pero sólo en los títulos de obras dramáticas aparece un modus intencional ávido del "efecto de realidad" que, a pesar del fracaso anunciado del principio de identidad, ancla aparentemente la palabra al mundo. Parece la misma intencionalidad que dirige los pasos del colector en el caso de romances, décimas, sonetos, etc., pero no lo es.

63 El equilibrio sólo es posible mediante la disposición adecuada de dos bandos en conflicto. La proporción (stasis) se logra ponderando los significados en ambas partes de esa balanza del pensar (dianoia) que tiene como objeto el propio pensamiento. La tradición filosófica en torno al asunto se observa en la perspectiva general del Órganon (Aristóteles, 1988b: 17a29 y 1988a: 72a1-25). Pero es Hermágoras quien aporta a la oratoria forense algunos enfoques de la doctrina estoica y de la escuela de los eclécticos. En su obra, hoy perdida, desarrolla la teoría aristotélica de los lugares comunes y específicos. La obra de Hermágoras ha perdurado a través de Cicerón, que reconoce su deuda con el de Temnos en su tratado juvenil de retórica (Cicerón, 1997: I, 2, 16). Para la tipificación de los status causae, los métodos que permiten que una propositio sea el objeto de reflexión de una cuantificación universal (causa infinita) o de un particular de ese mundo, véanse Quintiliano (1999: III, 6, 56-61 y VII, 2) y Cicerón (1997: I, 8, 10).

64 "Comenzaremos por su mismo título o inscripción, que hasta en eso erró V.m. llamándole impropísimamente Soledades, porque soledad es tanto como falta de compañía, y [...] V.m. introduce en su obra legiones de serranas y pastores, de entre los cuales nunca sale aquel pobre mozo naufragante [...], ¿cómo diablos pudo llamarse Soledad?" (Jáuregui: 2002: 6-7). En la cita, el título aparece, en segundo término, en singular, igual que sucede en Vicuña y Hoces [1633], pero también en plural "dual”, como sucede en Chacón y Hoces [1654]. Véanse, para el término Soledades, Jammes (1994: 59 ss.) y Micó (1990: 39). Más interesante en la cita es el carácter de la disyuntiva ("título o inscripción"): si esta no es excluyente, Jáuregui está sugiriendo que los rótulos de la mano de Góngora (Soledades) se encuentran más cercanos al epígrafe que al título (véanse las notas 7 y 9).

65 La falta de narratividad es una constante en la obra de Góngora (Blanco, 2012: cap. IV).

66 Todas las ediciones de las obras completas de Góngora incluyen el término "comedia", pero la más moderna lo evita en la cubierta (Carreira, 2000: 3) y en la portadilla, siguiendo los usos modernos de acortamiento del título. Es una decisión del editor que no debe ocultar el hecho de que "comedia" es una parte innegociable de estos títulos. 
Si bien es cierto que autor ${ }^{67}$ y colector se encuentran bajo la operativa del prépon (de lo que está permitido), en el caso de los títulos dramáticos, el modus intencional es, en términos retóricos, un argumento psicagógico — de persuasión de las almas ${ }^{68}$ - , cercano a la función "de seducción". Aquí, el icono "título-texto" puede incorporarse al grupo de figuras gorgianas ${ }^{69}$ si se relaja el kairós, el ajuste entre lo conveniente y el momento para expresarlo, pues nada obliga a ligar la obra dramática con su título de continuo si no es la función persuasiva.

En los poemas satíricos o burlescos (no dramáticos), en cambio, el generoso alcance del modus afecta (en el caso de Góngora, que no asistió nunca a su disposición) al colector, intencional sólo en cuanto a la observación del principio de no contradicción $^{70}$, y sujeto con firmeza al kairós bajo la operativa de largo alcance del clístico, al cual se someten todas y cada una de las composiciones poéticas en el intento de fomentar el icono como "figura del logos", lo que reduce este mundo textual suscrito a una simple experiencia cultural (bildungserlebnis ${ }^{71}$ ) en torno a la cuestión del género.

67 "Como los poetas, aun diciendo vaciedades, parecían conseguir fama a causa de su expresión, por este motivo la expresión fue en un principio poética, como la de Gorgias” (Aristóteles, 1990: 1404a24). La voz del poeta suscita la figura icónica, con el título en uno de los lugares del decorum, un argumento pragmático más de la retórica del prépon (véase la nota 38), en su sentido etimológico de "distinguirse" o "sobresalir" fisicamente.

68 Parafraseando a Gorgias, "Al alma se la puede disponer de una determinada manera según un orden preciso con el discurso retórico” (López Eire, 2000: 28).

69 Gorgias incorpora a su oratoria la figuración del pathos mediante fórmulas como la antítesis y el paralelismo (oposición de períodos o pensamientos) que encarnan la figura "título-texto" (véase Aristóteles, 1990: 1410a24 ss. y 1410b2). Entre los Schémata Gorgíeia se encuentran la parísosis y el homoiotéleuton.

70 El principio de identidad $(\mathrm{A}=\mathrm{A})$ tampoco se respeta cuando se emplean imágenes como la hidra de Gracián. Sólo una lectura literal, con toda su dificultad, defiende tal principio. Por su parte, el principio de no contradicción $(\sim$ [A es A y no es A]) se arruina constantemente. Sirva como botón de muestra la letrilla "Arroyo, en qué ha de parar" (447), que aparece intitulada como burlesca (ocupando el primer lugar) en la edición de Hoces (67), pero aparece bajo el marbete satírica en la de Vicuña (f. 64r). Es "inocente para quien se atiene a la letra", sostiene Jammes (1980: 102). Y esa inocencia lleva a Hoces a encabezarla con el epígrafe "A un Fulano de Arroyo", decisión que aparece duramente criticada en el Escrutinio sobre las impresiones de las obras poéticas de Don Luis de Góngora (Góngora, 1932: ap. V), cuyo autor —José Pérez de Ribas, según Carreira (1996: 31) - afirma que "se hizo a Rodrigo Calderón en su mayor privanza, y no a un Fulano de Arroyo, como dice el curioso [Hozes]: Si ya no es beatería, por no declarar el sujeto" (Jammes lee "batería" en el original, lo que no tiene sentido). El espíritu satírico de esta letrilla es también el motivo por el que no figura en el manuscrito Chacón. Don Antonio, beatus (recogido), lo rehúye, pues mortifica al que será el protector de su amigo a partir de 1617 (a quien, unos meses después, dedica, como reconciliación, el soneto "No más moralidades de corrientes", 448). Lo magro de la cuestión viene dado por el hecho de que, en la edición de Hoces de 1648 (67), veintisiete años después la muerte de don Rodrigo en la horca, el epígrafe se mantiene - la frase "Tener más orgullo que don Rodrigo en la horca", originada en la dignidad y arrepentimiento que mostró aquel en el cadalso, tuvo que actuar como prejuicio en la contención (véase Juderías, 1905: XIII, 334-365) — pero en la de 1654 (67) aparece "arroyo" (con minúscula). Al editor, sea quien fuere, ya no le preocupan las posibles suspicacias (incluidas las del censor) del apareo ficcional de don Rodrigo Calderón con una corriente de tan poco caudal (véanse Martos, 1998: 100 ss. y Jammes, 1987: 533-537). La discreción de la que se queja el autor del Escrutinio motiva el sacrificio no sólo del principio de identidad mediante la incursión del nombre común "arroyo", sino también el de no contradicción (es y no es "arroyo"). La descripción se ha sustituido por la alegoría, pero ambas se reducen al mismo modelo explicativo: el encadenamiento causal mediante la lógica de la identidad.

71 Proceso cognoscitivo opuesto al erlebnis, la "vivencia" o experiencia que precede a la interpretación (Gadamer, 1993: 44 ss.). 


\section{Obras citadas}

Abelardo, Pedro, "Logica ingredientibus", en Clemente Fernández (ed.): Los filósofos medievales. Selección de textos, Madrid, BAC, 1980, pp. 112-140.

Alighieri, Dante, Vita Nuova, ed. D. De Robertis, Milano-Napoli, Ricciardi, 1980.

Alonso, Dámaso, Estudios y ensayos gongorinos, Madrid, Gredos, 1955; reimpreso en Obras completas V, Góngora y el gongorismo, Madrid, Gredos, 1978, pp. 241-780.

Alonso, Dámaso, Góngora y el Polifemo, Madrid, Gredos, 1960; reimpreso en Obras completas VII. Góngora y el gongorismo, Madrid, Gredos, 1984.

Alonso, Dámaso, “El desgarrón afectivo en la poesía de Quevedo", Poesía Española. Ensayo de métodos y límites estilísticos, Madrid, Gredos, 1976, pp. 494-580.

Alonso Veloso, María José, “Antecedentes de los epígrafes de la poesía de Quevedo en la literatura clásica y del Siglo de Oro. Con una hipótesis sobre su autoría”, Revista de Literatura, 74 (2012), pp. 93-138.

Aristóteles, Categorías, en Tratados de lógica (Órganon), I, trad. de Miguel Candel, Madrid, Gredos, 1982a.

Aristóteles, Tópicos, en Tratados de lógica (Órganon), I, Madrid, Gredos, 1982b.

Aristóteles, Acerca del alma, trad. Tomas Calvo, Madrid, Gredos, 1988.

Aristóteles, Analíticos segundos, en Tratados de lógica (Órganon), II, trad. M. Candel, 1988a.

Aristóteles, Sobre la interpretación, en Tratados de lógica (Órganon), II, 1988b.

Aristóteles, Retórica, trad. Quintín Racionero, Madrid, Gredos, 1990.

Aristóteles, Metafísica, trad. María L. Alía Alberca, Madrid, Alianza, 2011.

Astrana Marín, Luis, Los orígenes del gongorismo, en Los Lunes de El Imparcial, Madrid, enero-febrero 1927.3

Besa Camprubí, Josep, El títol y el text. Una tipologia dels efects del títol en el text en poesia, Tesis doctoral, UAB, 2002, disponible en <http://hdl.handle.net/10803/4826> [consultado el 07/06/2017].

Biblia Vulgata, ed. de A. Colunga y L. Turrado, Madrid, BAC, 2002.

Blanco, Mercedes, "Góngora y el conceptismo”, en Joaquín Roses (ed.): Góngora Hoy I, II, III, Diputación Provincial de Córdoba, 2002, pp. 319-346.

Blanco, Mercedes, Góngora heroico. Las Soledades y la tradición épica, Madrid, Centro de Estudios Europa Hispánica, 2012.

Bochenski, Joseph M., "The Problem of Universals", en J. M. Bochenski, A. Church y N. Goodman: The Problem of Universals (A symposium), Indiana, Universidad de Notre Dame, 1956, pp. 33-57.

Boecio, A. M. S, In Isagogen Porphyrii Commenta..., ed. S. Brant, CSEL 48, Vienna/ Leipzig, 1906.

Capllonch, Begoña y Micó, José María, “La invención poética en las rimas gongorinas”, en J. Matas Caballero, José Ma ${ }^{\text {a }}$ Micó y J. Ponce Cárdenas (eds.): Góngora y el epigrama. Estudio sobre las décimas, Iberoamericana-Vervuert, 2013, pp. 243-260.

Carreira, Antonio, "La recepción de Góngora en el Siglo XVII: un candidato a la autoría del Escrutinio", en VV. AA.: Estudios sobre Góngora, Córdoba, Ayuntamiento y Academia, 1996, pp. 29-42.

Carreira, Antonio, Gongoremas, Barcelona, Península, 1998.

Carreira, Antonio, "Manuscritos y ecdótica", en J. Matas Caballero, José M. ${ }^{a}$ Micó y J. Ponce Cárdenas (eds.): Góngora y el epigrama. Estudio sobre las décimas, Iberoamericana-Vervuert, 2013, pp. 79-100. 
Carvallo, Luis Alfonso de, Cisne de Apolo, ed. A. Porqueras Mayo, Kassel, Reichenberger, 1997.

Castro, Adolfo de, (ed.), Poetas líricos de los Siglos XVI y XVII, I, Madrid, Rivadeneyra, 1854.

Church, Alonzo, "Proposiciones y oraciones", en Th. Moro Simpson (ed.): Semántica filosófica, problemas y discusiones, Buenos Aires, Siglo XXI, 1973, pp. 343-360.

Cicerón, La invención retórica, trad. S. Núñez, Madrid, Gredos, 1997.

Cicerón, Sobre el orador, trad. José J. Iso, Madrid, Gredos, 2002.

Culler, Jonathan, "En defensa de la sobreinterpretación”, en U. Eco (ed.): Interpretación y sobreinterpretación, Universidad de Cambridge, 1995, pp. 127-142.

Díaz de Ribas, Pedro, Discursos apologéticos por el estilo del "Polifemo" y las "Soledades”, Ms. 3906 (Cuesta Saavedra), BNE, ff. 68-91v.

Duchet, Claude, "La Fille abandonée et La Bète humaine. Éléments de titrologie romanesque", Littérature, 12 (1973), pp. 49-73.

Eco, Umberto, Obra abierta, Barcelona, Ariel, 1979.

Eco, Umberto, Los límites de la interpretación, Barcelona, Lumen, 1992.

Egido, Aurora, "La hidra bocal: sobre la palabra poética en el barroco", en Fronteras de la poesía en el barroco, Barcelona, Crítica,1990, pp. 9-55.

Espinosa, Pedro, Flores de poetas ilustres de España, ed. Belén Molina Huete, Sevilla, Fundación José Manuel Lara, 2005.

Frege, Glottob, “Sobre sentido y referencia”, en G. Frege: Estudios sobre semántica, Barcelona, Ariel, 1962, pp. 49-84.

Frege, Glottob, "El pensamiento: una investigación lógica”, en Margarita M. Valdés (comp.): Pensamiento y lenguaje. Problemas en la atribución de actitudes proposicionales, UNAM, 1996, pp. 23-48.

Gadamer, Hans-Georg, Verdad y método, Salamanca, Sígueme, 1993.

Genette, Gérard, Palimpsestos, Madrid, Taurus, 1989.

Genette, Gérard, Umbrales, Buenos Aires, Siglo XXI, 2001.

Góngora, Luis de, Obras en verso del Homero español que recogió Juan López de Vicuña, Madrid, Viuda de Luis Sánchez, 1627, ed. facsímil D. Alonso, Madrid, CSIC, 1963.

Góngora, Luis de, Obras de don Luis de Góngora [Manuscrito Chacón], ed. facsímil, Málaga, RAE- Caja de Ahorros de Ronda, 1991, 3 vols, disponible en <http://www.cervantesvirtual.com/nd/ark:/59851/bmcqn623> [consulta: 03/02/2015].

Góngora, Luis de, Todas las obras de don Luis de Góngora en varios poemas, recogidos por don Gonzalo de Hozes y Cordova, Madrid, Imprenta del Reyno, 1633 (1648 y 1654).

Góngora, Luis de, Delicias del Parnaso, Barcelona, Pedro Lacavallería, 1634.

Góngora, Luis de, Obras poéticas de Luis de Góngora, ed. R. Foulché-Delbosc, New York, The Hispanic Society of America, 1921.

Góngora, Luis de, Luis de Góngora y Argote, Obras completas, ed. J. Millé y Giménez e I. Millé y Giménez, Madrid, Aguilar, 1932.

Góngora, Luis de, Letrillas, ed. crítica R. Jammes, París, Ediciones Hispanoamericanas, 1963 (y Letrillas, Madrid, Castalia, 1980).

Góngora, Luis de, Sonetos, ed. crítica Biruté Ciplijauskaité, Madison, Wisc., Hispanic Seminary of Medieval Studies, 1981; ed. facsímil: Málaga, Junta de Andalucía, 2007.

Góngora, Luis de, Canciones y otros poemas de arte mayor, ed. José M. ${ }^{a}$ Micó, Madrid, Espasa-Calpe, 1990.

Góngora, Luis de, Soledades, ed. R. Jammes, Madrid, Castalia, 1994.

Góngora, Luis de, Romances, ed. A. Carreira, Barcelona, Quaderns Crema, 1998, 4 vols. 
Góngora, Luis de, Luis de Góngora. Obras Completas, ed. A. Carreira, Madrid, Fundación José A. de Castro, 2000, 2 vols.

Gracián, Baltasar, Arte de ingenio. Tratado de la Agudeza, ed. E. Blanco, Madrid, Cátedra, 1998.

Gracián, Baltasar, Agudeza y arte de ingenio, ed. facsímil de A. Egido, Zaragoza, Institución "Fernando el Católico", 2007.

Hare, Richard M., The Language of Moral, Universidad de Oxford, 1952; trad. G.R. Carrió y E. A. Rabossi: El lenguaje de la Moral, UNAM, 1975.

Hare, R. M., "Some Sub-Atomic Particles of Logic”, Mind, vol. 98, 389 (1989), pp. 23-37.

Hoek, Leo H., La marque du titre, La haya, Mouton, 1981.

Husserl, Edmund, Ideas relativas a una fenomenología pura y una filosofía fenomenológica, trad. J. Gaos, Madrid, FCE, 1985.

Isser, Wolfgang, El acto de leer, Madrid, Taurus, 1987.

Jammes, Robert, La obra poética de don Luis de Góngora y Argote, Madrid, Castalia, 1987. Jáuregui, Juan de, Antídoto contra la pestilente poesía de las Soledades, ed. José Manuel Rico García, Universidad de Sevilla, 2002.

Jauss, Hans R., Experiencia estética y hermenéutica literaria, Madrid, Taurus, 1986.

López Eire, Antonio, Esencia y objeto de la retórica, Salamanca, Universidad, 2000.

Luján Atienza, Ángel, "Estrategias discursivas del genus turpe en la poesía de Góngora”, en J. Roses (ed.) Góngora Hoy VIII. Góngora y lo prohibido: erotismo y escatología, Córdoba, Diputación Provincial, 2006, pp. 39-57.

Magno, Alberto, De praedicabilibus, en Beati Alberti Magni, Opera, I, recogido por Petri Iammy, Lugduni, 1651.

Martínez García, Juan J., Iconos de la voz poética en las letrillas burlescas de Góngora, Universidad de Málaga, 2015.

Martos, José Manuel, "La difusión de la poesía gongorina: el texto de Todas las obras de don Luis de Góngora de 1654”, Iberoromania, 47 (1998), pp. 97-106.

Micó, José M.a L La fragua de las Soledades. Ensayos sobre Góngora, Barcelona, Sirmio, 1990.

Molho, Maurice, "Soledades", Bulletin Hispanique, LXII (1960), pp. 249-285, reimpreso en Europe, 57 (1977a), pp. 91-139.

Molho, Maurice, Semántica y poética, Barcelona, Crítica, 1977 b.

Molina Huete, Belén, La trama del ramillete. Construcción y sentido de las Flores de poetas ilustres de Pedro Espinosa, Barcelona, Fundación José Manuel Lara, 2003.

Perelman, Chaïm y Olbrechts-Tyteca, Lucie, Tratado de la Argumentación. La nueva retórica, Madrid, Gredos, 1989.

Pérez Lasheras, Antonio, Más a lo moderno. (Sátira, burla y poesía en la época de Góngora), Zaragoza, Anejos de Tropelías, 1, 1995.

Pérez Lasheras, Antonio, "La crítica literaria en la polémica Gongorina", Bulletin Hispanique, 102, 2 (2000), pp. 429-452.

Pezzini, Sara, "Las décimas de Góngora: algunos problemas de edición”, en J. Matas Caballero, José M. ${ }^{a}$ Micó y J. Ponce Cárdenas (eds.): Góngora y el epigrama. Estudio sobre las décimas, Iberoamericana-Vervuert, 2013, pp. 101-122.

Quintiliano, Sobre la formación del orador, ed. A. Ortega Carmona, Salamanca, Universidad Pontificia, 1997-2001.

Reboul, Olivier, "La figure et l'argument", en M. Meyer (ed.): De la Métaphysique a la Rhétorique, Universidad de Bruselas, 1986, pp. 175-187.

Rifaterre, Michael, "Describing Poetic Structures", Yale French Studies, 36-37 (1966), pp. 232-282. 
Rojas, Pablo: "Luis Astrana Marín contra las vanguardias y contra Góngora", Rilce, 27, 2 (2011), pp. 441-462.

Salisbury, Juan de, Ioannis Saresberiensis episcopi Carnotensis Policratici sive De nugis curialium et vestigiis philosophorum libri VIII, ed. Clemens. C.I. Webb, 2 vols., Oxford, Typographeo Clarendoniano, 1909.

Vattimo, Gianni, "Hermenéutica analógica o hermenéutica anagógica", en M. Beuchot, A. Gómez Velasco y G. Vattimo: Hermenéutica analógica y hermenéutica débil, México, UNAM, 2006, pp. 21-41.

Vicente García, Luis M., “Arde la juventud: Eros y sus antídotos en la poesía de Góngora”, en Joaquín Roses (ed.): Góngora Hoy VIII, Góngora y lo prohibido: erotismo y escatología, Córdoba, Diputación Provincial, 2006, pp. 105-33.

Waltz, Angelus, “Augustini de Dacia O.P. Rotulus pugillaris”, Angelicum 6 (1929), pp. 253 278 y $548-574$. 